\title{
The Influence of Formula Concentration on the Absorption of Darbepoetin Alfa after Subcutaneous Administration
}

\author{
Tomonori Tayama ${ }^{1 *}$, Kazuki Kawakami', Hirotaka Takama', Daisuke Nakashima', \\ Hideji Tanaka', Takayuki Tsuji ${ }^{2}$, Tatsuo Yamamoto ${ }^{3}$, Sakuo Hoshi ${ }^{4}$ and Tadao Akizawa ${ }^{5}$ \\ 1Development Division, Kyowa Hakko Kirin Company Ltd., 1-6-1 Ohtemachi, Chiyoda-ku, Tokyo, 100-8185, Japan \\ 21st Department of Internal Medicine, Hamamatsu University School of Medicine, \\ 1-20-1 Handayama, Higashi-ku, Hamamatsu-shi, Shizuoka, 431-3192, Japan \\ ${ }^{3}$ Faculty of Health Promotional Sciences, Department of Health and Nutritional Science, \\ Hamamatsu University. 1230 Miyakoda-cho, Kita-ku, Hamamatsu-shi, shizuoka, 431-2102, Japan \\ ${ }^{4}$ Pharmaco-Business Innovation, Graduate School of Pharmaceutical Sciences, Faculty of Pharmaceutical Science, \\ The University of Tokyo. 7-3-1 Hongo, Bunkyo-ku, Tokyo 113-8654, Japan \\ ${ }^{5}$ Department of Nephrology, Showa University School of Medicine, 1-5-8 Hatanodai, Shinagawa-ku, Tokyo 142-8666, Japan
}

\begin{abstract}
Darbepoetin alfa (DA) is a hyperglycosylated analog of recombinant human erythropoietin (rHuEPO) that stimulates red blood cell production. The aim of this study is to investigate the influence of formula concentration on the absorption of DA after subcutaneous administration. Three separate studies were performed to assess the bioequivalence of four different formula concentrations of DA, $100 \mu \mathrm{g} / \mathrm{ml}$ as reference concentration, comparing with $10,30,200 \mu \mathrm{g} / \mathrm{ml}$ as test concentration, by the same dosage $(60 \mu \mathrm{g})$. The mean values of the pharmacokinetic parameters were similar after subcutaneous administration in each study. The $90 \%$ confidence intervals for logtransformed $\mathrm{C}_{\max }$ and $\mathrm{AUC}_{0-\mathrm{t}}$ were within the bioequivalence criteria $(0.8-1.25)$ in each study. In previous studies, the effect in absorption process of insulin was correlated to the formula concentration, the formula concentration of human growth hormone might not affected its absorption. The molecular weight is thought to be causally related to these results. The absorption rate of DA is not affected by its formula concentration because DA, which has relatively higher molecular weight $(36,000 \mathrm{Da})$, is primarily absorbed slowly via lymph vessels regardless of its concentration.
\end{abstract}

Keywords: Darbepoetin alfa; Absorption; Formula concentration; Subcutaneous administration; Bioequivalence

\section{Introduction}

Darbepoetin alfa (DA) is the hyperglycosylated analog of recombinant human erythropoietin (rHuEPO) that stimulates red blood cell production (erythropoiesis) by the same mechanism as rHuEPO (Macdougall, 2000). DA is a 165 -amino acid protein containing five $N$-linked oligosaccharide chains, whereas rHuEPO has only three $N$-linked oligosaccharide chains (Egrie et al., 2001). The additional oligosaccharide chains increase the molecular mass of the glycoprotein from approximately 30,400 to $36,000 \mathrm{Da}$ and the mean terminal half life of DA in non-dialysis patients after a single subcutaneous administration was found to be longer than that reported for subcutaneous administration of rHuEPO (Padhi et al., 2006).

There are a number of factors that modify the subcutaneous absorption profiles. A typical factor is the concentration of drug at the absorption site. The rate of transfer by most transport processes depends on the concentration difference between the two sides of the membrane (Gram, 1990).

There have been a few studies that investigated the influence of formula concentration on the absorption of insulin and human growth hormone (hGH) which are typical macromolecular drugs (Chantelau et al., 1985; Hildebrandt et al., 1983; Laursen et al., 1994; Blok et al., 1991; Vahl et al., 1996). Although DA is one of the macromolecular drugs, it has not yet been investigated from the same point of view. When subcutaneous administered, the formula concentration affects the absorption of insulin while that of hGH has not affect after subcutaneous administration. We think that these results are derived from the molecular weight differences (Insulin : 5,800 Da, hGH : 22,000 Da). Therefore, we verified the effects of the formula concentrations of DA, which has higher molecular weights $(36,000 \mathrm{Da})$, on its absorption rate after subcutaneous administration, using three bioequivalence studies.

\section{Materials and Methods}

\section{Subject}

Healthy male adults, 20-45 years of age and body mass indices of $18-26 \mathrm{~kg} \mathrm{~m}^{-2}$, were enrolled for three separate studies. Each study was approved by the investigators' institutional review board and all the subjects gave their informed consents in writing prior to the studies. Each subject was deemed to be healthy on the basis of normal medical history, physical examination, electrocardiogram and laboratory tests (routine hematologic test, serum biochemistry, urinalysis, hepatitis B surface antigen, hepatitis $\mathrm{C}$ antigen, and human immunodeficiency virus antibody).

*Corresponding author: Tomonori Tayama, Development Division, Kyowa Hakko Kirin Company Ltd., 1-6-1 Ohtemachi, Chiyoda-ku, Tokyo, 100-8185, Japan, Tel: +81-3-3282-0983; Fax: +81-3-3282-0335; E-mail: tomonori.tayama@kyowa-kirin.co.jp

Received November 10, 2009; Accepted December 21, 2009; Published December 22, 2009

Citation: Tayama T, Kawakami K, Takama H, Nakashima D, Tanaka H, et al. (2010) The Influence of Formula Concentration on the Absorption of Darbepoetin Alfa after Subcutaneous Administration. J Bioequiv Availab 2: 001-005. doi:10.4172/jbb.1000021

Copyright: (c) 2010 Tayama T, et al. This is an open-access article distributed under the terms of the Creative Commons Attribution License, which permits unrestricted use, distribution, and reproduction in any medium, provided the original author and source are credited. 
Citation: Tayama T, Kawakami K, Takama H, Nakashima D, Tanaka H, et al. (2010) The Influence of Formula Concentration on the Absorption of Darbepoetin Alfa after Subcutaneous Administration. J Bioequiv Availab 2: 001-005. doi:10.4172/jbb.1000021

The subjects were asymptomatic without known disease. Subjects were instructed to restrict smoking, taking other medications or alcohol and to avoid strenuous exertion throughout the study. These studies were conducted in compliance with the Good Clinical Practice regulations/guidelines and in accordance with the Declaration of Helsinki and subsequent amendments on experimentation in humans were obtained in all respects.

\section{Study design}

Three separate studies were performed to assess the bioequivalence of four different formula concentrations of DA: the reference formulation was $100 \mu \mathrm{g} / \mathrm{ml}$ and test formulations were $10 \mu \mathrm{g} / \mathrm{mL}$ (Study 1), $30 \mu \mathrm{g} / \mathrm{mL}$ (Study 2) and $200 \mu \mathrm{g} / \mathrm{mL}$ (Study 3), respectively. Each study was a single-centre, openlabel, randomized, two-treatment, two-period, crossover study. Using a 1:1 allocation ratio, subjects were randomized to one of the two treatment-sequence groups to receive either reference formulation or test formulation of DA to a dose of $60 \mu \mathrm{g}$ as their first subcutaneous administration (Period 1). In Period 2, the subjects subcutaneously received the alternate treatment after washout period. The choice of the dose for the studies was based upon the following criteria. To obtain adequate pharmacokinetic profiles and to minimize the influence of changes in the production of endogenous erythropoietin, a higher dose is preferable for a bioequivalence study. On the other hand, a higher dose of erythropoietin results in an increase in haematocrit and raises safety concerns and the carry-over effect on pharmacokinetics. Therefore we chose $60 \mu \mathrm{g}$ per subject as the most appropriate dose. It was planned that a total of up to 30 (Study 3) or 32 (Study 1 and 2) subjects, 15 (Study 3) or 16 (Study 1 and 2) subjects in each period, received DA in each study. Sample size was settled based on the results of the previous bioequivalence study using the different formulations of the same concentration. Subjects who withdrew from the study before completion were not to be replaced.

Each eligible subject was subcutaneously administered single dose of the reference and the test formulation over 41-day washout period which was inserted between each study period. The injections of $10 \mu \mathrm{g} / \mathrm{mL}$ formulation were carried out subcutaneously in six sites of both upper arms. Those of $30 \mu \mathrm{g} / \mathrm{mL}, 100$ $\mu \mathrm{g} / \mathrm{mL}$ and $200 \mu \mathrm{g} / \mathrm{mL}$ formulations were administered subcutaneously in two sites, one site each of upper arm, respectively. This over 41-day time frame was to allow for the red blood cell counts to return to baseline and the elimination of DA. Blood samples $(2 \mathrm{~mL})$ for the determination of serum concentration of DA were obtained before and after administration at exactly the following time points; 1, 2, 5, 8, 12, 24, 36, 48, 72, 96, 120, 168, 240 and $336 \mathrm{hr}$. Serum samples obtained by centrifugation were stored frozen until analysis.

\section{Serum darbepoetin alfa measurements}

Serum samples were analyzed with the use of the Quantikine in vitro diagnostics rHuEPO enzyme-linked immunosorbent assay (ELISA) kit (R\&D Systems, Minneapolis, MN, USA). The standard curve was constructed using DA, and quality control samples ensured individual assay quality. In validation tests, the intra- and inter-assay precision for spiked samples ranged from $5.1 \%$ to $11.0 \%$ and $4.4 \%$ to $6.1 \%$, respectively, and the intraand inter-assay accuracy ranged from $-11.0 \%$ to $-4.8 \%$ and from
$-10.7 \%$ to $8.4 \%$, respectively. The inter-assay precision and accuracy criterion for clinical serum samples were within $15 \%$ and $\pm 15 \%$, respectively. The range of detectable concentration for DA in serum was from $0.078 \mathrm{ng} / \mathrm{mL}$ to $5.00 \mathrm{ng} / \mathrm{mL}$. The ELISA for the pharmacokinetic investigation was performed at SRL Inc. (Tokyo and Kanagawa, Japan).

\section{Pharmacokinetic analysis}

For pharmacokinetic analyses, the predose serum concentration of endogenous erythropoietin for each treatment period was subtracted from all the postdose DA concentrations for each subject to adjust for the baseline erythropoietin level (DA and endogenous erythropoietin show a cross-reaction in the ELISA). The predose mean serum concentrations of endogenous level for each treatment period were $0.169-0.195 \mathrm{ng} / \mathrm{mL}$ and subtracted from all the postdose DA concentrations for each subject.

WinNonlin version 5.2 (Pharsight Corp., Mountain View, CA, USA) was used throughout the pharmacokinetic analyses. For the maximum serum drug concentration $\left(\mathrm{C}_{\max }\right)$ and the time to maximum serum drug concentration $\left(\mathrm{T}_{\max }\right)$, we used the observed values. The area under the serum concentration-time curve from zero to the time of the last quantifiable concentration $\left(\mathrm{AUC}_{0-\mathrm{t}}\right)$ was calculated according to the linear/log trapezoidal method using the actual times of measurements.

\section{Statistical analysis}

Statistical analysis was performed using the SAS System for Windows, Version 8.2 (SAS Institute, Inc., Cary, NC, USA). The point estimates and the $90 \%$ confidence intervals (CI) for the ratios of the geometric mean values of $\mathrm{C}_{\max }$ and $\mathrm{AUC}_{0-\mathrm{t}}$ and the difference of the arithmetic mean values of $\mathrm{T}_{\text {max }}$ for the test and reference formulation were calculated.

\section{Results}

Healthy male adults (20 - 39 years) were enrolled for each study.

The serum concentration-time profiles of test formulation were similar to those of reference formulation in all studies (Figure 1). After the administration, the mean serum concentration increased slowly, and reached the maximum concentration at 36 hr postdose.

The pharmacokinetic parameters of each formulation are summarized in Table 1. The mean value of $\mathrm{C}_{\max }, \mathrm{AUC}_{0-\mathrm{t}}$ and $\mathrm{T}_{\max }$ were similar in all studies.

The point estimates and $90 \% \mathrm{CI}$ of the ratios for log-transformed $\mathrm{AUC}_{0-\mathrm{t}}, \log$-transformed $\mathrm{C}_{\max }$, and $\mathrm{T}_{\max }$ are shown in Table 2. All the ratios for log-transformed $\mathrm{AUC}_{0-\mathrm{t}}$ and $\mathrm{C}_{\max }$ were within the bioequivalence criteria (0.80-1.25).

The safety profile was described by summarizing the nature, frequency, severity, and relationship to treatment of all adverse events; changes from baseline in laboratory hematology and biochemistry variables and in vital signs (blood pressure, heart rate and temperature), use of concomitant medications, and formation of antibodies to darbepoetin alfa and epoetin alfa. The overall incidence of adverse events was evenly distributed across all treatment groups, and no serious adverse events were reported. 


\section{Journal of Bioequivalence \& Bioavailability - Open Access \\ JBB/Vol.2 Issue 1}

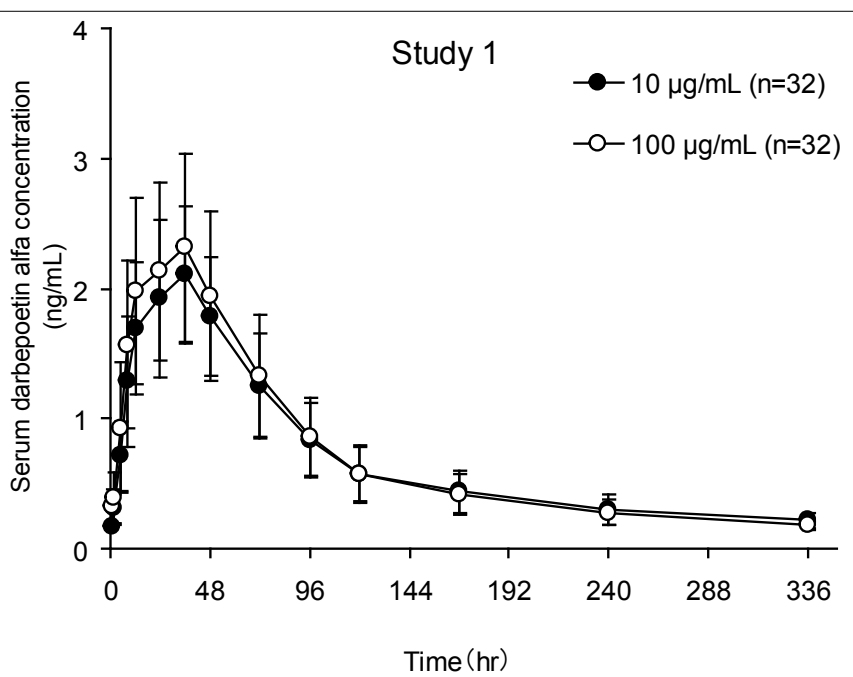

The predose mean serum concentrations of endgenous erythropoietin for $10 \mu \mathrm{g} / \mathrm{mL}$ and $100 \mu \mathrm{g} / \mathrm{mL}$ were $0.179 \mathrm{ng} / \mathrm{mL}$ and $0.169 \mathrm{ng} / \mathrm{mL}$, respectively.

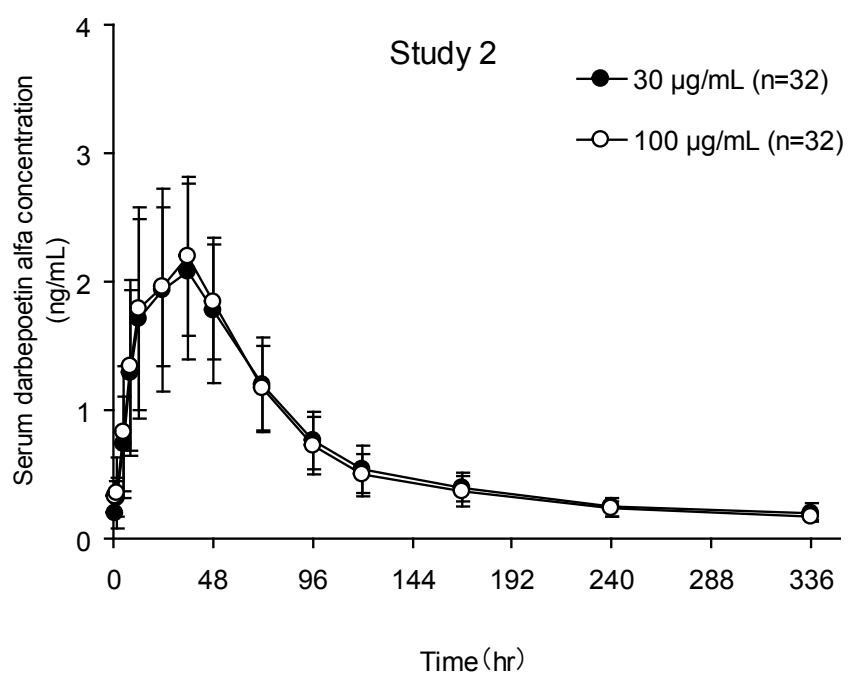

The predose mean serum concentrations of endgenous erythropoietin for 30 $\mu \mathrm{g} / \mathrm{mL}$ and $100 \mu \mathrm{g} / \mathrm{mL}$ were $0.175 \mathrm{ng} / \mathrm{mL}$ and $0.179 \mathrm{ng} / \mathrm{mL}$, respectively.

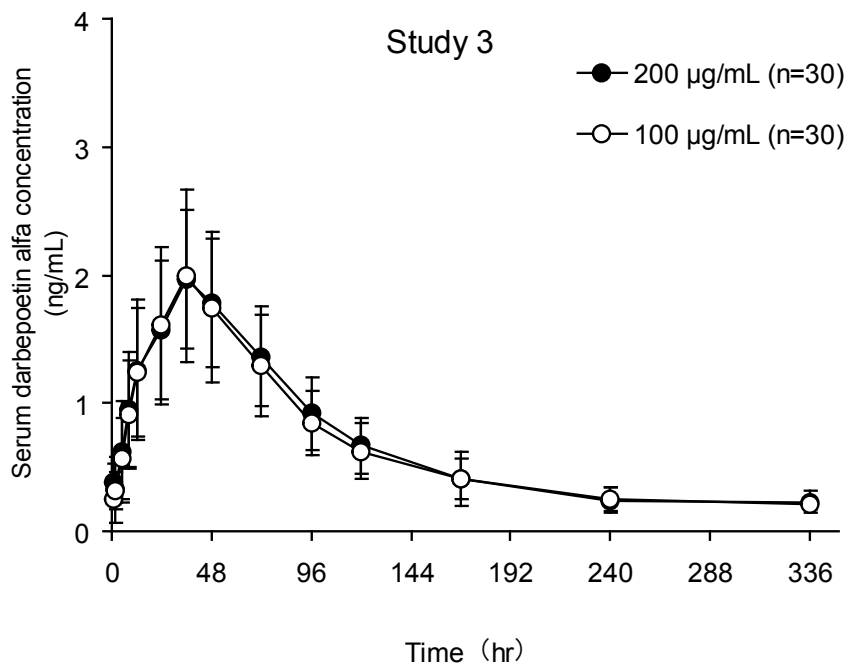

The predose mean serum concentrations of endgenous erythropoietin for $100 \mu \mathrm{g} / \mathrm{mL}$ and $200 \mu \mathrm{g} / \mathrm{mL}$ were $0.191 \mathrm{ng} / \mathrm{mL}$ and $0.195 \mathrm{ng} / \mathrm{mL}$, respectively.

Figure 1: Mean observed serum DA concentration after subcutaneous administration in healthy male adults. Healthy male adults subjects received administrations of (Study 1) $10 \mu \mathrm{g} / \mathrm{mL}$ or $100 \mu \mathrm{g} / \mathrm{mL}$, (Study 2) $30 \mu \mathrm{g} / \mathrm{mL}$ or $100 \mu \mathrm{g} /$ $\mathrm{mL}$, (Study 3) $200 \mu \mathrm{g} / \mathrm{mL}$ or $100 \mu \mathrm{g} / \mathrm{mL}$ (60 $\mu \mathrm{g}$ per subject). Standard deviations are indicated by error bars.
The overall safety data were consistent with those expected in a healthy study population, and did not present any concerns that suggests adverse effects due to formulation concentrations. Mean values for laboratory hematology and biochemistry variables (including hemoglobin) and vital signs were stable throughout the study. No antibodies were observed in any subject during the study.

\section{Discussion}

In three separate studies, the mean values of $\mathrm{C}_{\max }, \mathrm{AUC}_{0-\mathrm{t}}$ and $\mathrm{T}_{\max }$ of reference and test formulation were similar after subcutaneous administration. The $90 \% \mathrm{CI}$ of the ratios of the log-transformed for $\mathrm{AUC}_{0-\mathrm{t}}$ and $\mathrm{C}_{\max }$ were within 0.80-1.25. These results suggest that the formula concentration of DA does not affect its absorption after subcutaneous administration. Incidentally, it was difficult to investigate the potential impact of demographic characteristics in this study since demographic characteristics of healthy young volunteers in these studies were very similar. It was reported that the absorption rate constant of DA declined with age in a study using 20 - 80 years old subjects (Agoram et al., 2006). Also, it would appear that there was little influence of injection sites and injection times on absorption kinetics of subcutaneously administered DA in this study. Tolerable volume for subcutaneous administration is limited, therefore, we used multiple dosing in some dosing groups. In addition, it was reported that there was little influence of injection sites on the absorption of rHuEPO (30,400 Da), which is similar as DA in molecular weight (Jensen et al., 1994).

Some studies investigated the influence of formula concentration on the absorption of insulin and hGH which are typical macromolecular drugs (Chantelau et al., 1985; Hildebrandt et al., 1983; Laursen et al., 1994; Blok et al., 1991; Vahl et al., 1996).

In this previous study (Chantelau et al., 1985), the comparison of insulin pharmacokinetics was performed after its subcutaneous administration of several formula concentrations, 15, 40 and 100 units $/ \mathrm{ml}$, given in the same amount (10 units). This study suggested that insulin of low concentration was absorbed faster from the subcutaneous tissues than insulin of high concentration. Also, another study showed that the absorption of U40 insulin (40 units $/ \mathrm{mL}$ ) was significantly faster than of that of U100 insulin (100 units $/ \mathrm{mL})$, when given in the same amount (8 units) (Hildebrandt et al., 1983).

In the study of hGH (Laursen et al., 1994), the comparison of its pharmacokinetics was performed after subcutaneous administration of two formula concentrations, 12 and $56 \mathrm{IU} / \mathrm{mL}$. The patients received in random order a subcutaneous injection of 3 $\mathrm{IU} / \mathrm{m}^{2}$ of hGH. This study suggested that the absorption kinetics of the formulations of $\mathrm{hGH}$ containing $12 \mathrm{IU} / \mathrm{mL}$ and $56 \mathrm{IU} / \mathrm{mL}$ were similar. Another study also showed that hGH bioavailability with pen injection $(4 \mathrm{IU} / \mathrm{mL})$ was equals to that of injection by syringe (12 IU/mL) (Blok et al., 1991). The patients received in random order a subcutaneous injection of $3 \mathrm{IU} / \mathrm{m}^{2}$ of hGH. When given in the same amount $\left(3 \mathrm{IU} / \mathrm{m}^{2}\right)$, the changes observed in the pharmacokinetics of $\mathrm{hGH}$ among three different preparations, Norditropin 4IU/mL, $5.9 \mathrm{IU} / \mathrm{mL}$ and $11.7 \mathrm{IU} / \mathrm{mL}$, were moderate (Vahl et al., 1996).

The molecular weight is thought to be causally related to these 
Citation: Tayama T, Kawakami K, Takama H, Nakashima D, Tanaka H, et al. (2010) The Influence of Formula Concentration on the Absorption of Darbepoetin Alfa after Subcutaneous Administration. J Bioequiv Availab 2: 001-005. doi:10.4172/jbb.1000021

\begin{tabular}{|l|l|l|l|l|c|c|}
\hline \hline \multirow{2}{*}{ Parameter } & \multicolumn{2}{|l|}{ Study $1(\mathrm{n}=32)$} & \multicolumn{3}{l|}{ Study 2(n=32) } & \multicolumn{2}{l|}{ Study 3 $(\mathrm{n}=30)$} \\
\cline { 2 - 7 } & $\begin{array}{l}10 \mu \mathrm{g} / \mathrm{mL} \\
\text { Mean } \pm \mathrm{SD}\end{array}$ & $\begin{array}{l}100 \mu \mathrm{g} / \mathrm{mL} \\
\text { Mean } \pm \mathrm{SD}\end{array}$ & $\begin{array}{l}30 \mu \mathrm{g} / \mathrm{mL} \\
\text { Mean } \pm \mathrm{SD}\end{array}$ & $\begin{array}{l}100 \mu \mathrm{g} / \mathrm{mL} \\
\text { Mean } \pm \mathrm{SD}\end{array}$ & $\begin{array}{l}200 \mu \mathrm{g} / \mathrm{mL} \\
\text { Mean } \pm \mathrm{SD}\end{array}$ & $\begin{array}{c}100 \mu \mathrm{g} / \mathrm{mL} \\
\text { Mean } \pm \mathrm{SD}\end{array}$ \\
\hline $\mathrm{C}_{\max }(\mathrm{ng} / \mathrm{mL})$ & $2.142 \pm 0.560$ & $2.365 \pm 0.693$ & $2.120 \pm 0.734$ & $2.284 \pm 0.738$ & $1.982 \pm 0.529$ & $2.010 \pm 0.660$ \\
\hline $\mathrm{AUC}_{0-\mathrm{t}}(\mathrm{ng} \cdot \mathrm{hr} / \mathrm{mL})$ & $203.5 \pm 52.3^{* 1}$ & $220.2 \pm 62.9$ & $196.7 \pm 59.7$ & $193.2 \pm 49.0$ & $196.3 \pm 49.6^{* 2}$ & $188.9 \pm 56.1$ \\
\hline $\mathrm{T}_{\max }(\mathrm{hr})$ & $31.5 \pm 8.5$ & $31.9 \pm 9.4$ & $33.8 \pm 7.7$ & $35.3 \pm 6.0$ & $37.6 \pm 4.2$ & $39.2 \pm 8.3$ \\
\hline
\end{tabular}

$\mathrm{SD}=$ standard deviation, $\mathrm{C}_{\max }=$ the maximum serum drug concentration, $\mathrm{AUC}_{0-\mathrm{t}}=$ the area under the serum concentration-time curve from time zero to the time of the last quantifiable concentration, $\mathrm{T}_{\max }=$ the time to maximum serum drug concentration.

*1: One subject was excluded, because the AUC could not be estimated accurately due to the lack of $336 \mathrm{hr}$ data.

*2: One subject was excluded, because the AUC was overestimated due to the deviations of the last sampling point.

Table 1: Pharmacokinetic parameters of DA after subcutaneous administration.

\begin{tabular}{|c|c|c|c|}
\hline & \multirow[t]{2}{*}{ Point Estimates } & \multicolumn{2}{|c|}{ 90\% Confidence Intervals } \\
\hline & & Lower & Upper \\
\hline \multicolumn{4}{|c|}{ Study $1(10 \mu \mathrm{g} / \mathrm{mL} / 100 \mu \mathrm{g} / \mathrm{mL})$} \\
\hline $\mathrm{C}_{\max }$ & 0.907 & 0.837 & 0.982 \\
\hline $\mathrm{AUC}_{0-\mathrm{t}}$ & 0.930 & 0.878 & 0.986 \\
\hline$T_{\max }$ & -0.38 & -3.36 & 2.61 \\
\hline \multicolumn{4}{|c|}{ Study $2(30 \mu \mathrm{g} / \mathrm{mL} / 100 \mu \mathrm{g} / \mathrm{mL})$} \\
\hline $\mathrm{C}_{\max }$ & 0.922 & 0.861 & 0.988 \\
\hline $\mathrm{AUC}_{0-\mathrm{t}}$ & 1.004 & 0.939 & 1.073 \\
\hline $\mathrm{T}_{\max }$ & -1.50 & -3.92 & 0.92 \\
\hline \multicolumn{4}{|c|}{ Study $3(200 \mu \mathrm{g} / \mathrm{mL} / 100 \mu \mathrm{g} / \mathrm{mL})$} \\
\hline $\mathrm{C}_{\max }$ & 0.971 & 0.890 & 1.060 \\
\hline $\mathrm{AUC}_{0-\mathrm{t}}$ & 0.993 & 0.834 & 1.183 \\
\hline$T_{\max }$ & 4.00 & 1.71 & 6.29 \\
\hline
\end{tabular}

$\mathrm{C}_{\max }=$ the maximum drug concentration, $\mathrm{AUC}_{0-\mathrm{t}}=$ the area under the serum concentration-time curve from time zero to the time of the last quantifiable concentration, $\mathrm{T}_{\max }=$ the time to maximum serum drug concentration.

Table 2: Bioequivalence analysis for pharmacokinetic parameter among 4 formulations.

results. In a diffusion-controlled process, large molecular is expected to have a slower penetration rates than smaller ones. A primary factor in the relatively-fast absorption rate of insulin is presumed to be its molecular weight of 5,800 Da, which is close to the upper limit for transcapillary absorption (Kraegen et al., 1985; Schou, 1961). hGH with a molecular weight of 22,000 Da is absorbed more slowly than insulin after subcutaneous administration (Russo and Moore, 1982). In rat muscle, there was a 10-fold difference in clearance rates of labeled carbohydrates, with molecular weight ranging from 182 to 90,000. However, for small molecules, the absorption rate is similar and is limited by blood flow (Sund and Schou, 1964; Bederka et al., 1971). It appears that molecules of low molecular weight are primarily absorbed via the capillaries, while molecules having relatively higher molecular weight are absorbed primarily via lymph vessels (Barnes and Trueta, 1941). In sheep model, the lymphatic absorption of group compounds with increasing molecular weights (5-fluoro-2'-deoxyridine, 2,500 Da; inulin, 5,200 Da; cytochrome C, 12,300 Da; IFN- $\alpha, 19,000 \mathrm{Da}$ ) showed a direct correlation between molecular weight and the extent of popliteal lymph recovery (Supersaxo et al., 1990; Supersaxo et al., 1991). Furthermore in sheep model, $48 \%$ of the systemic bioavailability of insulin following subcutaneous administration was contributed by the lymphatic system (Charman et al., 2001). Likewise, erythropoietin with a molecular weight of 30,400 Da demon- strated lymphatic uptake of $83.9 \%$ of the injected dose (McLennan et al., 2005). This different absorption pathway may be related to structural differences between blood and lymphatic endothelial cell lining. The endothelia lining of the blood capillaries have a continuous and uninterrupted subendothelial basement. In contrast, terminal lymphatics does not possess this membrane. The lack of a basal lamia around lymphatic capillaries may be the major functional importance in facilitating access of interstitial macromolecules to the lymphatic system (O'Morchoe and O'Morchoe, 1987). In addition, adjacent endothelial cells of terminal lymphatics may have gaps which makes it possible for macromolecules that goes up to $1 \mu \mathrm{m}$ diameter to enter the lymphatics (Leak, 1971).

As described above, we presented following hypothesis; absorption profiles of small molecular are affected by the drug concentration because both drug and medium goes through blood capillaries at the same time. Macromolecule is primarily absorbed via lymph vessels slowly and does not go through the blood capillaries as medium does. In other words, absorption rate of macromolecule is not affected by the formula concentration since it is primarily absorbed slowly via lymph vessels regardless of its concentration. The data shown in this study was limited to DA and there has been few studies investigated as similar point of view in other macromolecular drugs. However, the data which can confirm the presented hypothesis, will be available in the 


\section{Journal of Bioequivalence \& Bioavailability - Open Access JBB/Vol.2 Issue 1}

near future because many macromolecular drugs will are under development. The conclusion of this study is that the formula concentration of DA, which is one of the macromolecular drugs, does not affect its absorption rate after subcutaneous administration as hypothesis above.

\section{Acknowledgements}

We thank Shiho Noda and our colleagues in Kyowa Hakko Kirin Company Ltd for their excellent technical assistance.

\section{References}

1. Agoram B, Sutjandra L, Sullivan JT (2007) Population pharmacokinetics of darbepoetin alfa in healthy subjects. Br J Clin Pharmacol 63: 41-52. »CrossRef » PubMed » Google Scholar

2. Barnes JM, Trueta J (1941) Absorption of bacteria, Toxins and snake Venoms from the Tissues. The Lancet Office 1: 623-6. »CrossRef » PubMed » Google Scholar

3. Bederka J, Takemori AE, Miller JW (1971) Absorption rates of various substances administered intramuscularly. Eur J Pharmacol 15: 132-6. »CrossRef » PubMed » Google Scholar

4. Blok GJ, van der Veen EA, Susgaard S, Lausen F (1991) Influence of concentration and injection volume on the bioavailability of subcutaneous growth hormone: comparison of administration by ordinary syringe and by injection pen. Pharmacol Toxicol 68: 355-9. » CrossRef » PubMed » Google Scholar

5. Chantelau E, Sonnenberg GE, Rajab A, Römisch J, Berger M (1985) Absorption of subcutaneously administered regular human and porcine insulin in different concentrations. Diabete Metab 11: 106-10. CrossRef $^{2}$ $»$ PubMed » Google Scholar

6. Charman SA, McLennan DN, Edwards GA, Porter CJ (2001) Lymphatic absorption is a significant contributor to the subcutaneous bioavailability of insulin in a sheep model. Pharm Res 18: 1620-6. » CrossRef » PubMed » Google Scholar

7. Egrie JC, Browne JK (2001) Development and characterization of novel erythropoiesis stimulating protein (NESP). Nephrol Dial Transplant 16: 313. » CrossRef » PubMed » Google Scholar

8. Gram TE (1990) Drug absorption and distribution. Modern pharmacology $3^{\text {rd }}$ edn 21-38. »CrossRef » PubMed » Google Scholar

9. Hildebrandt P, Sestoft L, Nielsen SL (1983) The absorption of subcutaneously injected short-acting soluble insulin : Influence of injection technique and concentration. Diabetes Care 6: 459-62. » CrossRef » PubMed » Google Scholar

10. Jensen JD, Jensen LW, Madsen JK (1994) The pharmacokinetics of recombinant human erythropoietin after subcutaneous injection at different sites. Eur J Clin Pharmacol 46: 333-7. » CrossRef » PubMed » Google Scholar
11. Kraegen EW, Chisholm DJ (1985) Pharmacokinetics of insulin. Implications for continuous subcutaneous insulin infusion therapy. Clin Pharmacokinet 10: 303-14. » CrossRef » PubMed » Google Scholar

12.Laursen T, Susgaard S, Jensen FS, Jørgensen JO, Christiansen JS (1994) Absorption kinetics of two highly concentrated preparations of growth hormone : $12 \mathrm{IU} / \mathrm{ml}$ compared to $56 \mathrm{IU} / \mathrm{ml}$. Pharmacol Toxicol 74: 54-7. »CrossRef » PubMed » Google Scholar

13. Leak LV (1971) Studies on the permeability of lymphatic capillaries. J Cell Biol 50: 300-23. »CrossRef » PubMed » Google Scholar

14. Macdougall IC (2000) Novel erythropoiesis stimulating protein. Seminars in Nephrology 20: 375-81. » CrossRef » PubMed » Google Scholar

15. McLennan DN, Porter CJ, Edwards GA, Martin SW, Heatherington AC, et al. (2005) Lymphatic absorption is the primary contributor to the systemic availability of epoetin Alfa following subcutaneous administration to sheep. J Pharmacol Exp Ther 313: 345-51. » CrossRef » PubMed » Google Scholar

16. O'Morchoe CC, O'Morchoe PJ (1987) Differences in lymphatic and blood capillary permeability: ultrastructural-functional correlations. Lymphology 20: 205-9. » CrossRef » PubMed » Google Scholar

17.Padhi D, Ni L, Cooke B, Marino R, Jang G (2006) An extended terminal half-life for darbepoetin alfa: results from a single-dose pharmacokinetic study in patients with chronic kidney disease not receiving dialysis. Clin Pharmacokinet 45: 503-10. »CrossRef » PubMed » Google Scholar

18. Russo L, Moore WV (1982) A comparison of subcutaneous and intramuscular administration of human growth hormone in the therapy of growth hormone deficiency. J Clin Endocrinol Metab 55: 1003-6. » CrossRef » PubMed » Google Scholar

19. Schou J (1961) Absorption of drugs from subcutaneous connective tissue. Pharmacol Rev 13: 441-64. » CrossRef » PubMed » Google Scholar

20. Sund RB, Schou J (1964) The determination of absorption rates from rat muscle: An experimental approach to kinetic descriptions. Acta Pharmacol Toxicol 21: 313-25. » CrossRef » PubMed » Google Scholar

21. Supersaxo A, Hein WR, Steffen H (1990) Effect of molecular weight on the lymphatic absorption of water-soluble compounds following subcutaneous administration. Pharm Res 7: 167-9. » CrossRef » PubMed » Google Scholar

22. Supersaxo A, Hein WR, Steffen H (1991) Mixed micelles as a proliposomal lymphotropic drug carrier. Pharm Res 8: 1286-91. »CrossRef » PubMed » Google Scholar

23. Vahl N, Jensen SB, Rasmussen MH, Susgaard S, Jørgensen JO, et al. (1996) Bioavailability of recombinant Human Growth Hormone in Different concentrations and formulations. Pharmacol Toxicol 79: 144-9. » CrossRef » PubMed » Google Scholar 